\title{
TNF wt Allele
}

National Cancer Institute

\section{Source}

National Cancer Institute. TNF wt Allele. NCI Thesaurus. Code C51526.

Human TNF wild-type allele is located in the vicinity of $6 p 21.3$ and is approximately $3 \mathrm{~kb}$ in length. This allele, which encodes tumor necrosis factor protein, is involved in a wide spectrum of biological processes including cell proliferation, differentiation, apoptosis, lipid metabolism, and coagulation. Aberrant alleles have been associated with a variety of diseases, including autoimmune diseases, insulin resistance, and cancer. 